\title{
KORELASI INDEKS NINO 3.4 DAN SOUTHERN OSCILLATION INDEX (SOI) DENGAN VARIASI CURAH HUJAN DI SEMARANG
}

\author{
The Correlation Between Nino 3.4 Index and Southern Oscillation Index \\ (SOI) with the Variation of Rainfall in Semarang
}

\author{
Anistia Malinda Hidayat ${ }^{1)^{*}}$, Usman Efendi1), Lisa Agustina1), Paulus Agus Winarso') \\ 1) Sekolah Tinggi Meteorologi Klimatologi dan Geofisika, Jalan Perhubungan I No. 5 \\ Kel. Pondok Betung, Kec. Pondok Aren, Tangerang Selatan, Banten. \\ *E-mail: anistia.malinda@gmail.com
}

\begin{abstract}
Intisari
Semarang merupakan salah satu wilayah di Indonesia yang rawan terdampak bencana hidrometeorologi. Sejumlah wilayah di Semarang merupakan daerah rawan kekeringan, sementara di wilayah lainnya merupakan daerah langganan banjir tiap tahunnya. Salah satu parameter yang memiliki keterkaitan erat dengan fenomena hidrometeorologi adalah El Nino Southern Oscillation (ENSO). Sebagai sirkulasi tropis non musiman, ENSO memiliki peran penting terhadap variasi curah hujan yang diamati. Penelitian terkait ENSO telah banyak dilakukan sebelumnya, namun belum ada penelitian tekait yang dilakukan di Semarang yang notabene merupakan daerah rawan bencana hidrometeorologi, sehingga fluktuasi ENSO menarik untuk dikaji di wilayah ini. Penelitian ini bertujuan untuk menganalisis korelasi fenomena global laut atmosfer terhadap distribusi curah hujan di wilayah Semarang. Dalam jangka waktu 15 tahun (2001-2015), pengaruh dari ENSO dianalisis menggunakan korelasi temporal untuk menentukan dampak dari ENSO pada curah hujan yang diamati di enam pos pengamatan hujan di Semarang. Analisis tersebut menunjukkan bahwa korelasi antara anomali Suhu Permukaan Laut (SPL) di wilayah Nino 3.4 dengan curah hujan diamati secara signifikan pada lima pos pengamatan hujan selama periode September Oktober November (SON) dengan rentang nilai korelasi antara -0.598 sampai dengan -0.679. Sementara itu, korelasi variabilitas curah hujan dengan Southern Oscillation Index (SOI) menunjukan nilai yang berkisar antara 0.561 sampai dengan 0.780. Curah hujan yang diamati umumnya selalu berkurang pada tahun-tahun dimana nilai indeks Nino 3.4 positif dan nilai SOI negatif, sedangkan curah hujan diamati meningkat pada tahun-tahun dimana nilai indeks Nino 3.4 negatif dan nilai SOI yang positif.
\end{abstract}

Kata Kunci : ENSO, Indeks Nino 3.4, SOI, Curah Hujan.

\begin{abstract}
Semarang is one of the most hydrometeorological disaster-prone region in Indonesia. Some areas in Semarang are drought-prone areas, while the other regions are flood-prone areas which experiences flood each year. One of the parameter associated with hydrometeorological phenomenon is the El Nino Southern Oscillation (ENSO). As a non-seasonal tropical circulation, ENSO plays an important roles against observed rainfall variability. There have been previous researches carried out related to ENSO, but there has not been related research conducted in Semarang, which is in fact a hydrometeorological disasters-prone area. Therefore, ENSO fluctuations is an interesting topic of study in this region. This study aims to analyze the correlation between the global phenomenon of atmospheric sea and the rainfall distribution in the Semarang region. In a span of 15 years (2001-2015), the influence of ENSO was analyzed by using temporal correlation to determine the effect of ENSO on the observed rainfall in six rain observatories throughout Semarang. The analysis showed that the correlation between Sea Surface Temperature (SST) anomalies in the Nino 3.4 region and rainfall was significantly observed in the five rain observation posts during the September October November period (SON) with a correlation value ranging between -0.598 to $-0,679$. Meanwhile, rainfall variability correlation with the Southern Oscillation Index (SOI) shows values ranging from 0.561 to 0.780 . The amount of observed rainfall will decrease in years with positive 3.4 Nino index value and negative SOI value, while the amount of observed rainfall increases in years with negative 3.4 Nino index value and positive SOI value.
\end{abstract}

Keywords : ENSO, Nino 3.4 Index, SOI, Rainfall. 


\section{PENDAHULUAN}

Indonesia merupakan negara maritim yang dilewati oleh garis khatulistiwa. Indonesia juga terletak di antara dua benua yaitu benua Asia dan benua Australia, serta terletak di antara dua samudra yaitu Samudra Hindia dan Samudra Pasifik. Berkaitan dengan posisinya, wilayah Indonesia dipengaruhi oleh sirkulasi monsun yang berbalik arah dua kali dalam setahun. Sirkulasi monsun ini menyebabkan adanya musim hujan yang terjadi pada periode monsun Asia (Oktober April) dan musim kemarau pada periode monsun Australia (Mei - September). Karena Indonesia terletak di ekuator, hal ini menyebabkan banyak faktor yang mempengaruhi sistem musim di Indonesia. Meskipun monsun terjadi secara periodik, tetapi awal musim hujan dan musim kemarau tidak selalu sama sepanjang tahun (Tjasyono, 2008). Menurut Yamagata et al. (2002), hal ini disebabkan musim di Indonesia dipengaruhi oleh fenomena global seperti EI Nino/La Nina, Osilasi Selatan, dan Dipole Mode Event (DME) atau Indian Ocean Dipole (IOD).

Perubahan iklim yang terjadi membuat beberapa fenomena tersebut lebih sering terjadi. Salah satunya adalah EI Nino Southern Oscillation (ENSO). ENSO adalah sebuah fenomena penyimpangan dari suhu muka laut di Samudra Pasifik dekat ekuator bagian tengah dan timur. ENSO merupakan Global Climate System yang terjadi nonperiodik. El Nino merupakan fase ENSO hangat dan La Nina sebagai fase ENSO dingin. El Nino diidentifikasi melalui terjadinya kenaikan suhu muka laut di wilayah perairan Pasifik Ekuator, sedangkan La Nina adalah kondisi sebalikannya pada wilayah yang sama. El Nino dapat menyebabkan turunnya suhu muka laut di wilayah perairan Indonesia dan La Nina cenderung meningkatkan suhu permukaan laut di perairan Indonesia (Philander, 1989; Kovats, 2000; Xiao \& Mechoso, 2009; Luo et al., 2010; Aldrian et al., 2011; Wang et al., 2017; Fitria \& Pratama, 2013).

Untuk mengetahui fenomena ENSO digunakan beberapa indeks, yaitu ONI (Oceanic Nino Index) dan SOI (Southern Oscillation Index). Oceanic Nino Index (ONI) didasarkan pada Suhu Permukaan Laut (SPL) dari rata-rata di wilayah Nino 3.4, dan merupakan ukuran utama untuk memantau, menilai dan memprediksi ENSO. Sedangkan penentuan indeks SOI didasarkan pada perbedaan tekanan udara permukaan laut antara Tahiti dan Darwin (Zakir et al., 2009). Sementara itu, dalam rentang tahun 2001-2015 telah terjadi lima kali fenomena El Nino dengan intensitas lemah hingga sangat kuat. Sementara itu, La Nina dengan intensitas menengah terjadi dua kali pada tahun 2007-2008 dan 2010-2012.

Fenomena ENSO ini akan berdampak pada intensitas curah hujan yang diamati di Indonesia. Apabila fenomena El Nino terjadi pada musim kemarau maka cenderung memperparah dampak kekeringan dan apabila terjadi pada musim hujan akan mengurangi curah hujan diamati pada musim tersebut. Sedangkan jika fenomena La Nina terjadi, maka cenderung meningkatkan intensitas curah hujan diamati, baik di musim kemarau maupun musim hujan (llahude \& Nontji, 1999; Aldrian, 2002 \& 2008; Utami, et al., 2011; Suwandi et al., 2014). Adanya fenomena El Nino dan La Nina harus diwaspadai khususnya pada daerah yang rawan akan bencana hidrometeorologi seperti Kota Semarang.

Kota Semarang terletak pada $6^{\circ} 50^{\prime}-7^{\circ} 10^{\prime}$ LS dan $109^{\circ} 35^{\prime}-110^{\circ} 50^{\prime}$ BT dengan luas wilayah mencapai $373,70 \mathrm{~km}^{2}$. Sebelah barat Kota Semarang dibatasi dengan Kabupaten Kendal, sebelah timur dibatasi Kabupaten Demak, sebelah selatan dibatasi Kabupaten Semarang, dan sebelah utara dibatasi oleh Laut Jawa dengan panjang garis pantai mencapai $13,6 \mathrm{~km}$. Kondisi topografi Kota Semarang yang terdiri dari daerah perbukitan, dataran rendah dan daerah pantai dengan berbagai kemiringan membuat wilayah Semarang rawan akan terjadinya bencana alam, termasuk bencana hidrometeorologi. Berdasarkan data laporan kebencanaan Badan Nasional Penanggulangan Bencana (BNPB), tercatat 177 kejadian bencana alam telah terjadi dalam rentang tahun 1990-2015, meliputi bencana banjir, rob, tanah longsor, kekeringan, puting beliung, perubahan iklim, dan gelombang pasang. Prioritas utama bencana alam secara terarah di Kota Semarang terfokus pada empat bencana, yaitu banjir, banjir rob, tanah longsor, dan kekeringan (BPBD Kota Semarang, 2015).

Kota Semarang mempunyai potensi banjir dan banjir rob di wilayah dataran rendah serta tanah longsor di titik tertentu pada saat musim penghujan. Disisi lain, Kota Semarang juga rentan akan bencana kekeringan pada saat musim kemarau (Pratiwi et al., 2016). Potensi bencana tersebut akan lebih besar apabila dipengaruhi oleh fenomena ENSO. Berkaitan dengan hal tersebut, penulis melakukan penelitian guna mengetahui pengaruh fenomena ENSO terhadap variasi hujan di Kota Semarang. Melalui penelitian ini diharapkan bisa diketahui daerah mana saja di Kota Semarang yang mendapat pengaruh fenomena ENSO dan seberapa kuat pengaruhnya, sehingga membantu proses mitigasi bencana.

\section{METODE}

Dalam penelitian ini, data yang digunakan adalah data curah hujan tahun 2001-2015 dari enam pos pengamatan hujan di Semarang, yaitu Stasiun Klimatologi Semarang, Stasiun Meteorologi Maritim Semarang, Stasiun Meteorologi Ahmad Yani, Genuk, Mangkang dan Sumur Jurang Gunung Pati. Sedangkan, data pembanding yang digunakan berupa anomali 
suhu permukaan laut Nino 3.4 (SST Index Nino 3.4) yang diambil dari situs NOAA (www.esrl.noaa.gov/psd/gcos_wgsp/Timeseries/ Nino34/) dan data SOI diambil dari situs Bureau of Meteorology (www.bom.gov.au).

Data hujan diolah ke dalam bentuk anomali curah hujan. Perhitungan anomali curah hujan diamati bulanan bertujuan untuk mengetahui sifat dari hujan yang terjadi pada suatu wilayah dalam rentang waktu tertentu. Anomali curah hujan merupakan selisih antara nilai pengamatan curah hujan pada bulan ke-i dengan nilai rata-rata curah hujan dalam periode bulan yang sama. Anomali data curah hujan dihitung dengan menggunakan rumus sebagai berikut:

Anomali curah hujan $=X i-\left(\frac{1}{N} \sum_{i=1}^{n} X i\right) \ldots . .(1)$ dengan:

$X_{i}=$ jumlah curah hujan pada bulan ke- $i(\mathrm{~mm})$

$N=$ jumlah hari hujan yang diamati pada bulan ke$i$ untuk menghitung nilai rata-rata curah hujan

Data anomali curah hujan, indeks suhu muka laut Nino 3.4, serta SOI dicari rata-ratanya setiap tiga bulan berdasarkan dari sesi monsun, yaitu September-Oktober-November (SON), Desember-Januari-Februari (DJF), Maret-AprilMei (MAM), dan Juni-Juli-Agustus (JJA). Analisis korelasi dihitung antara anomali curah hujan diamati terhadap Indeks Nino 3.4 dan anomali curah hujan terhadap SOI setiap tiga bulan untuk periode SON, DJF, MAM, dan JJA. Dari analisis korelasi ini menghasilkan koefisien korelasi yang menunjukan tingginya derajat hubungan antara curah hujan diamati, SPL, dan SOI. Sementara itu, nilai korelasi antara curah hujan diamati dan indeks Nino 3.4 dihitung dengan rumus sebagai berikut:

$$
r=\frac{n \sum X Y-\sum X \sum Y}{\sqrt{n \sum X^{2}-\left(\sum X\right)^{2}} \sqrt{n \sum Y^{2}-\left(\sum Y\right)^{2}}}
$$

dengan:

$r=$ koefisien korelasi antara $\mathrm{X}$ dan $\mathrm{Y}$

$X=$ rata-rata bulanan dari SOI maupun indeks Nino 3.4

$Y=$ curah hujan diamati bulanan dari pos pengamatan hujan

Tabel 1. Interpretasi Nilai $r$ (koefisien korelasi).

\begin{tabular}{cc}
\hline Nilai $\mathbf{r}$ (korelasi) & Keterangan \\
\hline $0,00-0,199$ & Sangat lemah \\
$0,20-0,399$ & Lemah \\
$0,40-0,599$ & Cukup kuat \\
$0,60-0,799$ & Kuat \\
$0,80-1,000$ & Sangat kuat \\
\hline \multicolumn{2}{c}{ Sumber : Sugiyono (2012). }
\end{tabular}

\section{HASIL DAN PEMBAHASAN}

Fenomena ENSO didefinisikan ketika anomali SPL selama 3 bulan berturut-turut lebih dari atau sama dengan +0.5 (indikasi fenomena El Nino) dan kurang dari atau sama dengan -0.5 (indikasi fenomena La Nina). Berdasarkan intensitasnya, ENSO kemudian dikelompokkan lagi menjadi ENSO lemah (anomali SPL 0.5 hingga 0.9), sedang (1.0 hingga 1.4), kuat (1.5 hingga 1.9) dan sangat kuat $(\geq 2.0)$. Kategorisasi ENSO juga dapat ditentukan berdasarkan variasi SOI. ENSO dikategorikan sebagai EI Nino apabila nilai SOI kurang dari -7 dan terjadi secara kontinyu atau berkelanjutan. Apabila nilai SOI selalu berada diatas +7 secara kontinyu atau berkelanjutan, maka menunjukkan terjadinya indikasi La Nina.

Dalam rentang tahun 2001 hingga 2015, anomali indeks di wilayah Nino 3.4 mencapai maksimum pada November 2015 dengan nilai anomali adalah 2.57 (Gambar 1). Di sisi lain, indeks Nino 3.4 mencapai minimum pada Januari 2008, dengan nilai anomali -1.79. Dalam 15 tahun ini, fenomena La Nina intensitas menengah teramati dari Agustus 2007-2008 dan 2010-2012. Sementara itu, fenomena El Nino teramati sebanyak 5 kali dengan intensitas lemah hingga sangat kuat. Fenomena El Nino intensitas lemah teramati pada tahun 2004-2005 dan 20062007. Intensitas menengah dari fenomena $\mathrm{El}$ Nino terjadi pada tahun 2002-2003 dan 20092010. Dimana, El Nino dengan intensitas sangat kuat terjadi pada tahun 2014-2015.

Gambar 2 menunjukkan grafik SOI dari tahun 2001-2015. Grafik ini menunjukkan SOI terendah terjadi pada Februari 2005 dengan nilai SOI adalah -28.6, sedangkan SOI tertinggi terjadi pada Desember 2010 dengan nilai SOI adalah 27.1. Nilai korelasi ( $r$ ) dari anomali SPL di wilayah Nino 3.4 dengan SOI adalah -0.69. Korelasi negatif ini menunjukkan bahwa anomali SPL di wilayah Nino 3.4 dengan SOI memiliki hubungan berbanding terbalik. Ketika anomali SPL di wilayah Nino 3.4 indeks meningkat, SOI akan menurun. Di sisi lain, ketika nilai dari anomali SPL di wilayah Nino 3.4 menurun, SOI akan meningkat.

Pada pembahasan selanjutnya akan membahas mengenai hasil analisis korelasi antara anomali indeks Nino 3.4 dengan curah hujan diamati dan juga SOI dengan curah hujan diamati pada beberapa daerah di Semarang, dimana nilai koefisien korelasi dianggap signifikan ketika peluang untuk mencapai tingkat nyata $(p)$ adalah $\leq 0.05$. 


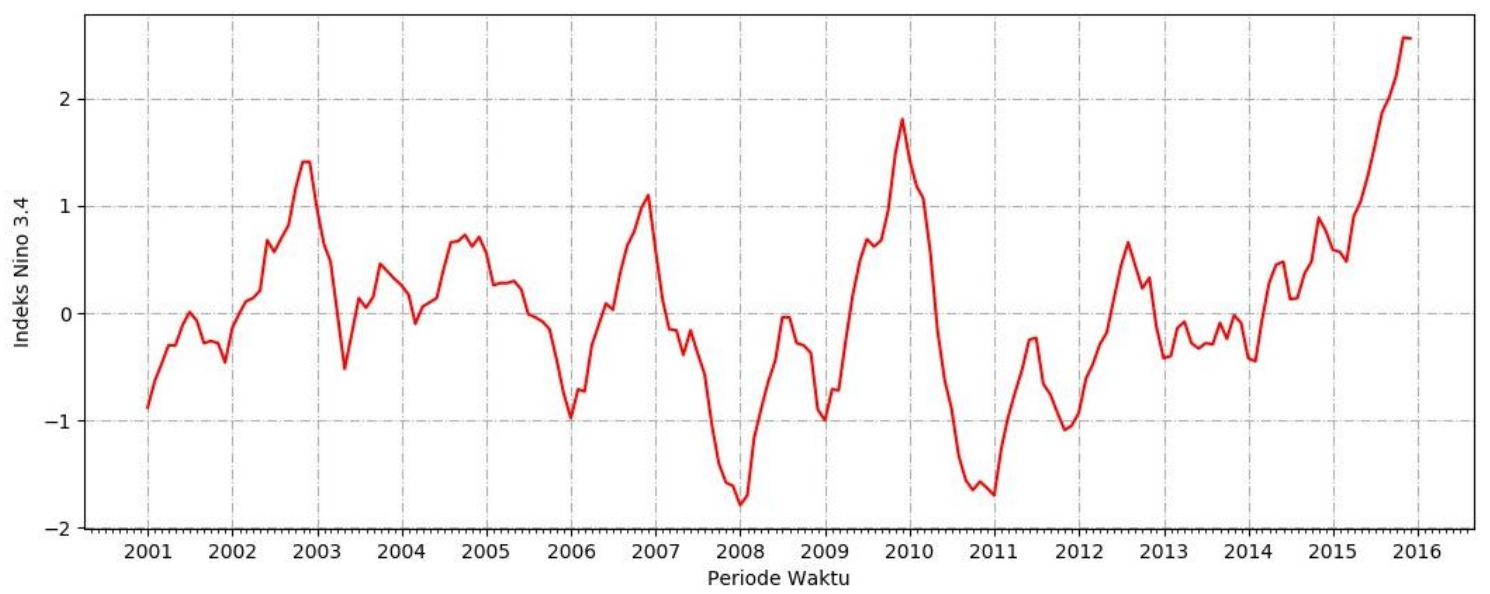

Gambar 1. Fluktuasi indeks Nino 3.4 sejak Januari 2001 sampai Desember 2015.

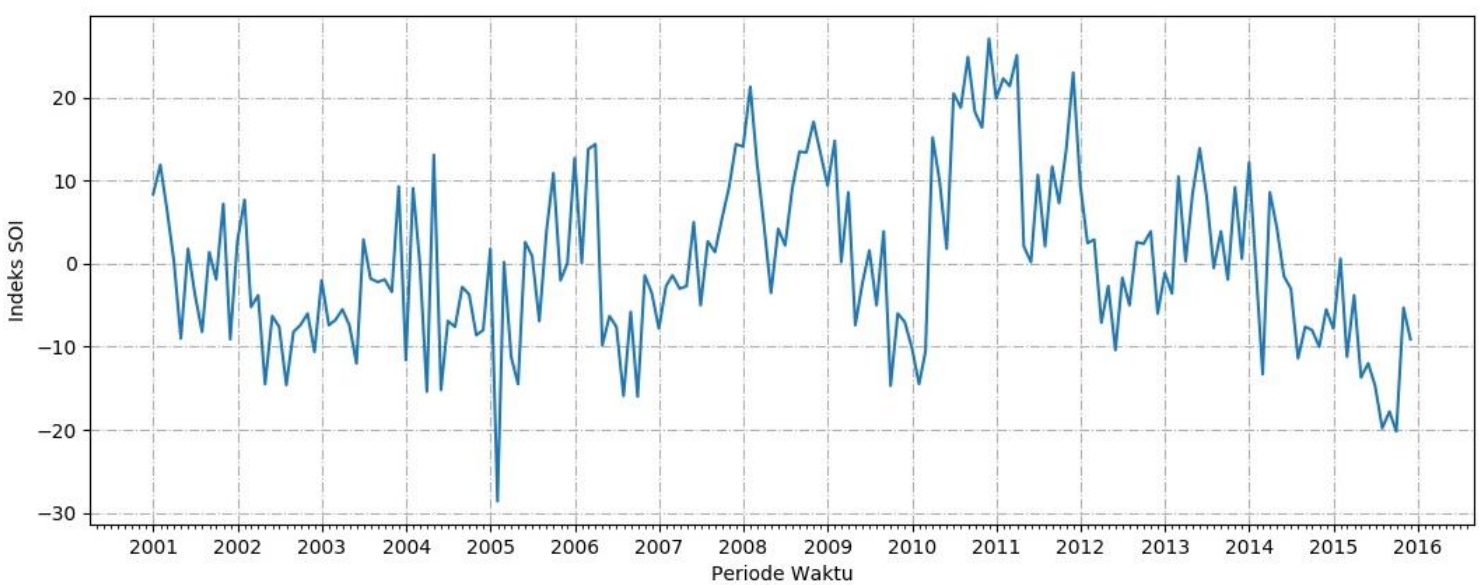

Gambar 2. Fluktuasi nilai SOI sejak Januari 2001 sampai Desember 2015.

\subsection{Korelasi Indeks Nino 3.4 dan SOI dengan Curah Hujan Periode SON}

Berdasarkan analisis korelasi antara indeks anomali dari curah hujan dengan indeks Nino 3.4, terdapat korelasi kuat $(r>0.6)$ antara dua komponen ini yang terjadi hampir di semua pos pengamatan hujan (Tabel 2). Sementara itu, hanya satu daerah, Gunung Pati yang tidak memiliki dampak signifikan dari korelasi ini.

Tabel 2. Korelasi curah hujan dan indeks Nino 3.4 pada periode SON.

\begin{tabular}{cccc}
\hline $\begin{array}{c}\text { Curah Hujan } \\
\text { Diamati }\end{array}$ & $\mathbf{r}$ & $\begin{array}{c}\mathbf{p}- \\
\text { value }\end{array}$ & $\begin{array}{c}\text { Ketera- } \\
\text { ngan }\end{array}$ \\
\hline $\begin{array}{c}\text { Stasiun } \\
\text { Meteorologi } \\
\text { Maritim }\end{array}$ & -0.679 & 0.005 & Signifikan \\
\hline $\begin{array}{c}\text { Stasiun } \\
\text { Meteorologi } \\
\text { Ahmad Yani }\end{array}$ & -0.676 & 0.006 & Signifikan \\
\hline $\begin{array}{c}\text { Stasiun } \\
\text { Klimatologi } \\
\text { Semarang }\end{array}$ & -0.677 & 0.006 & Signifikan \\
\hline $\begin{array}{c}\text { Genuk } \\
\text { Sumur Jurang } \\
\text { Gunung Pati }\end{array}$ & -0.629 & 0.012 & Signifikan \\
\hline Mangkang & -0.598 & 0.271 & $\begin{array}{c}\text { Tidak } \\
\text { Signifikan }\end{array}$ \\
\hline
\end{tabular}

Nilai korelasi negatif menunjukkan hubungan berbanding terbalik antara anomali curah hujan dengan indeks Nino 3.4. Hal ini berarti, bila indeks Nino 3.4 meningkat maka curah hujan akan menurun, sedangkan jika indeks Nino 3.4 menurun maka anomali curah hujan akan meningkat.

Tabel 3 menunjukkan hasil dari analisis korelasi antara anomali curah hujan diamati dengan SOI.

Tabel 3. Korelasi curah hujan dengan SOI pada periode SON.

\begin{tabular}{cccc}
\hline $\begin{array}{c}\text { Curah Hujan } \\
\text { Diamati }\end{array}$ & $\mathbf{r}$ & $\begin{array}{c}\text { p- } \\
\text { value }\end{array}$ & $\begin{array}{c}\text { Ketera- } \\
\text { ngan }\end{array}$ \\
\hline $\begin{array}{c}\text { Stasiun } \\
\text { Meteorologi } \\
\text { Maritim }\end{array}$ & 0.780 & 0.001 & Signifikan \\
\hline $\begin{array}{c}\text { Stasiun } \\
\text { Meteorologi } \\
\text { Ahmad Yani }\end{array}$ & 0.765 & 0.001 & Signifikan \\
\hline $\begin{array}{c}\text { Stasiun } \\
\text { Klimatologi } \\
\text { Semarang }\end{array}$ & 0.734 & 0.002 & Signifikan \\
\hline $\begin{array}{c}\text { Genuk } \\
\text { Sumur Jurang } \\
\text { Gunung Pati }\end{array}$ & 0.666 & 0.007 & Signifikan \\
\hline Mangkang & 0.629 & 0.030 & Signifikan \\
\hline
\end{tabular}


Dapat dilihat bahwa terdapat korelasi signifikan antara SOI dengan anomali curah hujan diamati pada seluruh wilayah. Dari enam pos pengamatan hujan yang disebutkan diatas, lima diantaranya menunjukkan hubungan kuat $(r>$ 0.6), sedangkan hanya pos pengamatan hujan Sumur Jurang Gunung Pati yang mengindikasikan nilai korelasi cukup kuat $(0.4<r<0.6)$. nilai korelasi positif mengindikasikan bahwa hubungan antara anomali dari curah hujan diamati dengan SOI adalah hubungan searah. Artinya jika nilai SOI naik mengindikasikan terjadinya La Nina yang secara umum akan meningkatkan curah hujan di sebagian wilayah Indonesia, sedangkan jika nilai SOI turun umumnya merupakan indikasi terjadinya El Nino, maka curah hujan di sebagian wilayah Indonesia umumnya juga akan menurun.

\subsection{Korelasi Indeks Nino 3.4 dan SOI dengan Curah Hujan Periode DJF}

Tabel 4. Korelasi curah hujan dengan indeks Nino 3.4 pada periode DJF.

\begin{tabular}{cccc}
\hline $\begin{array}{c}\text { Curah } \\
\text { Hujan } \\
\text { Diamati }\end{array}$ & $\mathbf{r}$ & $\begin{array}{c}\text { p- } \\
\text { value }\end{array}$ & Keterangan \\
\hline $\begin{array}{c}\text { Stasiun } \\
\text { Meteorologi } \\
\text { Maritim }\end{array}$ & -0.206 & 0.461 & $\begin{array}{c}\text { Tidak } \\
\text { Signifikan }\end{array}$ \\
\hline $\begin{array}{c}\text { Stasiun } \\
\text { Meteorologi } \\
\text { Ahmad Yani }\end{array}$ & -0.289 & 0.297 & $\begin{array}{c}\text { Tidak } \\
\text { Signifikan }\end{array}$ \\
\hline $\begin{array}{c}\text { Stasiun } \\
\text { Klimatologi } \\
\text { Semarang }\end{array}$ & -0.190 & 0.499 & $\begin{array}{c}\text { Tidak } \\
\text { Signifikan }\end{array}$ \\
\hline $\begin{array}{c}\text { Genuk } \\
\text { Sumur }\end{array}$ & -0.228 & 0.414 & $\begin{array}{c}\text { Tidak } \\
\text { Signifikan }\end{array}$ \\
\hline $\begin{array}{c}\text { Jurang } \\
\text { Gunung Pati }\end{array}$ & 0.448 & 0.094 & $\begin{array}{c}\text { Tidak } \\
\text { Signifikan }\end{array}$ \\
\hline Mangkang & -0.179 & 0.524 & $\begin{array}{c}\text { Tidak } \\
\text { Signifikan }\end{array}$ \\
\hline
\end{tabular}

Tabel 4 menunjukkan hasil analisis korelasi antara anomali curah hujan diamati dengan anomali indeks Nino 3.4. Selama periode Desember-Januari-Februari, tidak terdapat korelasi signifikan antara curah hujan diamati dengan indeks Nino 3.4. Korelasi antara curah hujan diamati dengan indeks Nino 3.4 pada lima tempat pengamatan curah hujan menunjukkan korelasi negatif, namun hanya wilayah Sumur Jurang Gunung Pati yang mengindikasikan adanya korelasi positif. Korelasi positif ini menunjukkan bahwa selama periode DJF, anomali curah hujan dengan anomali SPL di wilayah Nino 3.4 menunjukkan hubungan searah. Hubungan searah ini menggambarkan bahwa ketika indeks anomali SPL di wilayah Nino 3.4 meningkat, maka curah hujan yang diamati di Sumur Jurang Gunung Pati cenderung meningkat dengan hubungan korelasi yang dikategorikan cukup kuat, yaitu 0.448 .

Tabel 5. Korelasi curah hujan dengan SOI pada periode DJF.

\begin{tabular}{cccc}
$\begin{array}{c}\text { Curah } \\
\text { Hujan } \\
\text { Diamati }\end{array}$ & R & $\begin{array}{c}\text { p- } \\
\text { value }\end{array}$ & Keterangan \\
\hline $\begin{array}{c}\text { Stasiun } \\
\text { Meteorologi } \\
\text { Maritim }\end{array}$ & 0.251 & 0.368 & $\begin{array}{c}\text { Tidak } \\
\text { Signifikan }\end{array}$ \\
\hline $\begin{array}{c}\text { Stasiun } \\
\text { Meteorologi } \\
\text { Ahmad Yani }\end{array}$ & 0.303 & 0.272 & $\begin{array}{c}\text { Tidak } \\
\text { Signifikan }\end{array}$ \\
\hline $\begin{array}{c}\text { Stasiun } \\
\text { Klimatologi } \\
\text { Semarang }\end{array}$ & 0.212 & 0.447 & $\begin{array}{c}\text { Tidak } \\
\text { Signifikan }\end{array}$ \\
\hline $\begin{array}{c}\text { Genuk } \\
\text { Sumur }\end{array}$ & 0.220 & 0.431 & $\begin{array}{c}\text { Tidak } \\
\text { Signifikan }\end{array}$ \\
\hline $\begin{array}{c}\text { Jurang } \\
\text { Gunung Pati }\end{array}$ & -0.292 & 0.291 & $\begin{array}{c}\text { Tidak } \\
\text { Signifikan }\end{array}$ \\
\hline Mangkang & 0.186 & 0.507 & $\begin{array}{c}\text { Tidak } \\
\text { Signifikan }\end{array}$ \\
\hline
\end{tabular}

Sementara itu, korelasi antara curah hujan diamati dengan SOI di periode DJF juga menurun drastis pada periode DJF (Tabel 5). Dapat dilihat bahwa tidak ada korelasi signifikan antara SOI dengan curah hujan diamati pada enam pos pengamatan hujan ini di Semarang. Dari enam pos pengamatan hujan ini, hanya wilayah Sumur Jurang Gunung Pati yang menunujukkan korelasi negatif, walaupun bukan merupakan korelasi signifikan.

\subsection{Korelasi Indeks Nino 3.4 dan SOI dengan Curah Hujan Periode MAM}

Pada periode MAM, indeks Nino 3.4 tidak memberikan dampak besar pada curah hujan diamati seperti yang ditunjukkan oleh Tabel 6 .

Tabel 6. Korelasi curah hujan dengan indeks Nino 3.4 pada periode MAM.

\begin{tabular}{cccc}
\hline $\begin{array}{c}\text { Curah Hujan } \\
\text { Diamati }\end{array}$ & $\mathbf{R}$ & $\begin{array}{c}\mathbf{p}- \\
\text { value }\end{array}$ & Keterangan \\
\hline $\begin{array}{c}\text { Stasiun } \\
\text { Meteorologi } \\
\text { Maritim }\end{array}$ & 0.311 & 0.260 & $\begin{array}{c}\text { Tidak } \\
\text { Signifikan }\end{array}$ \\
\hline $\begin{array}{c}\text { Stasiun } \\
\text { Meteorologi } \\
\text { Ahmad Yani }\end{array}$ & 0.424 & 0.116 & $\begin{array}{c}\text { Tidak } \\
\text { Signifikan }\end{array}$ \\
$\begin{array}{c}\text { Stasiun } \\
\text { Klimatologi } \\
\text { Semarang }\end{array}$ & 0.434 & 0.106 & $\begin{array}{c}\text { Tidak } \\
\text { Signifikan }\end{array}$ \\
\hline Genuk & 0.060 & 0.831 & $\begin{array}{c}\text { Tidak } \\
\text { Signifikan } \\
\text { Tidak } \\
\text { Signifikan }\end{array}$ \\
\hline $\begin{array}{c}\text { Sumur Jurang } \\
\text { Gunung Pati }\end{array}$ & 0.441 & 0.100 & $\begin{array}{c}\text { Tidak } \\
\text { Signifikan }\end{array}$ \\
\hline Mangkang & 0.257 & 0.355 &
\end{tabular}


Selama periode ini, terdapat korelasi positif antara antara curah hujan diamati dengan indeks Nino 3.4 di semua pos pengamatan hujan. Artinya, peningkatan anomali SPL di wilayah Nino 3.4 akan diikuti dengan peningkatan curah hujan di periode MAM di seluruh pos pengamatan curah hujan, namun hubungan ini memiliki hubungan yang tidak signifikan. Berdasarkan keterangan nilai korelasi, indeks Nino 3.4 memiliki hubungan lemah hingga cukup kuat dengan variasi curah hujan diamati di Semarang. Berdasarkan Tabel 4 dan 6, selama bulan Desember hingga Mei, indeks Nino 3.4 tidak memberikan dampak signifikan pada curah hujan di seluruh wilayah Semarang.

Seperti periode bulan sebelumnya, DJF, curah hujan pada periode MAM tidak memiliki korelasi signifikan dengan SOI, ditunjukkan pada Tabel 7. Berdasarkan keterangan nilai korelasi, SOI memiliki korelasi sangat lemah hingga lemah dengan variasi curah hujan di Semarang. Berdasarkan Tabel 5 dan 7, variasi nilai SOI tidak memberikan dampak signifikan pada curah hujan di seluruh wilayah Semarang selama Desember hingga Mei.

Tabel 7. Korelasi curah hujan dengan SOI pada periode MAM.

\begin{tabular}{|c|c|c|c|}
\hline $\begin{array}{c}\text { Curah Hujan } \\
\text { Diamati }\end{array}$ & $\mathbf{r}$ & $\begin{array}{c}p- \\
\text { value }\end{array}$ & Keterangan \\
\hline $\begin{array}{c}\text { Stasiun } \\
\text { Meteorologi } \\
\text { Maritim }\end{array}$ & 0.103 & 0.715 & $\begin{array}{c}\text { Tidak } \\
\text { Signifikan }\end{array}$ \\
\hline $\begin{array}{c}\text { Stasiun } \\
\text { Meteorologi } \\
\text { Ahmad Yani }\end{array}$ & -0.231 & 0.407 & $\begin{array}{c}\text { Tidak } \\
\text { Signifikan }\end{array}$ \\
\hline $\begin{array}{c}\text { Stasiun } \\
\text { Klimatologi } \\
\text { Semarang }\end{array}$ & -0.139 & 0.622 & $\begin{array}{c}\text { Tidak } \\
\text { Signifikan }\end{array}$ \\
\hline Genuk & 0.021 & 0.942 & $\begin{array}{c}\text { Tidak } \\
\text { Signifikan }\end{array}$ \\
\hline $\begin{array}{l}\text { Sumur Jurang } \\
\text { Gunung Pati }\end{array}$ & -0.142 & 0.614 & $\begin{array}{c}\text { Tidak } \\
\text { Signifikan }\end{array}$ \\
\hline Mangkang & -0.068 & 0.809 & $\begin{array}{c}\text { Tidak } \\
\text { Signifikan }\end{array}$ \\
\hline
\end{tabular}

\subsection{Korelasi Indeks Nino 3.4 dan SOI dengan Curah Hujan Periode JJA}

Analisis data pada Tabel 8 menunjukkan bahwa selama periode JJA, indeks Nino 3.4 memiliki korelasi cukup kuat dengan variasi curah hujan diamati di Semarang, kecuali pos pengamatan hujan di Sumur Jurang Gunung Pati. Korelasi cukup kuat diamati secara signifikan di pos pengamatan hujan Stasiun Meteorologi Maritim, yang memiliki nilai koefisien korelasi 0,51723 . Sementara 5 pos pengamatan hujan lainnya menunjukkan hubungan negatif antara indeks Nino 3.4 dengan variasi curah hujan diamati.
Tabel 8. Korelasi curah hujan dengan indeks Nino 3.4 pada periode JJA.

\begin{tabular}{|c|c|c|c|}
\hline $\begin{array}{c}\text { Curah Hujan } \\
\text { Diamati }\end{array}$ & $r$ & $\begin{array}{c}\mathrm{p}- \\
\text { value }\end{array}$ & $\begin{array}{l}\text { Ketera- } \\
\text { ngan }\end{array}$ \\
\hline $\begin{array}{c}\text { Stasiun } \\
\text { Meteorologi } \\
\text { Maritim }\end{array}$ & -0.517 & 0.048 & Signifikan \\
\hline $\begin{array}{c}\text { Stasiun } \\
\text { Meteorologi } \\
\text { Ahmad Yani }\end{array}$ & -0.465 & 0.081 & $\begin{array}{c}\text { Tidak } \\
\text { Signifikan }\end{array}$ \\
\hline $\begin{array}{l}\text { Stasiun } \\
\text { Klimatologi } \\
\text { Semarang }\end{array}$ & -0.437 & 0.103 & $\begin{array}{c}\text { Tidak } \\
\text { Signifikan }\end{array}$ \\
\hline Genuk & -0.487 & 0.066 & $\begin{array}{c}\text { Tidak } \\
\text { Signifikan }\end{array}$ \\
\hline $\begin{array}{l}\text { Sumur Jurang } \\
\text { Gunung Pati }\end{array}$ & -0.146 & 0.603 & $\begin{array}{c}\text { Tidak } \\
\text { Signifikan }\end{array}$ \\
\hline Mangkang & -0.450 & 0.093 & $\begin{array}{c}\text { Tidak } \\
\text { Signifikan }\end{array}$ \\
\hline
\end{tabular}

Ketika dibandingkan dengan indeks Nino 3.4, SOI lebih memiliki korelasi signifikan dengan curah hujan diamati di Semarang. Berdasarkan informasi pada Tabel 9, korelasi signifikan antara SOI dan curah hujan diamati di hampir seluruh pos pengamatan hujan dengan koefisien korelasi antara 0,568 - 0,685 (cukup kuat - kuat), kecuali di Sumur Jurang Gunung Pati yang menunjukkan korelasi sangat lemah. Pada periode ini, semua korelasi adalah positif yang menunjukkan bahwa adanya hubungan searah antara SOI dengan variasi curah hujan diamati di Semarang.

Tabel 9. Korelasi antara curah hujan dengan SOI pada periode JJA.

\begin{tabular}{cccc}
\hline $\begin{array}{c}\text { Curah Hujan } \\
\text { Diamati }\end{array}$ & $\mathbf{r}$ & $\begin{array}{c}\text { p- } \\
\text { value }\end{array}$ & Keterangan \\
\hline $\begin{array}{c}\text { Stasiun } \\
\text { Meteorologi } \\
\text { Maritim }\end{array}$ & 0.685 & 0.005 & Signifikan \\
\hline $\begin{array}{c}\text { Stasiun } \\
\text { Meteorologi } \\
\text { Ahmad Yani }\end{array}$ & 0.611 & 0.016 & Signifikan \\
\hline $\begin{array}{c}\text { Stasiun } \\
\text { Klimatologi } \\
\text { Semarang }\end{array}$ & 0.599 & 0.018 & Signifikan \\
\hline Genuk & 0.568 & 0.027 & Signifikan \\
\hline $\begin{array}{c}\text { Sumur Jurang } \\
\text { Gunung Pati }\end{array}$ & 0.162 & 0.564 & $\begin{array}{c}\text { Tidak } \\
\text { Mangkang }\end{array}$ \\
\hline
\end{tabular}

\section{KESIMPULAN}

Dalam rentang tahun 2001 - 2015, anomali SPL tertinggi di wilayah Nino 3.4 diamati pada November adalah 2.57. Sedangkan, anomali SPL terendah terjadi pada Januari 2008, yaitu -1.79. Selama rentang waktu penelitian tahun 20012005, telah terjadi lima kali El Nino dan dua kali 
dengan intensitas kuat. Sementara itu, nilaitertinggi dari SOI yang diamati pada bulan Desember 2010 adalah 27.1, sedangkan nilai terendahnya yang diamati pada bulan Februari 2005 adalah -28.6. Berdasarkan analisis temporal, curah hujan yang diamati di keenam pos pengamatan cenderung berkurang pada tahuntahun dimana nilai indeks Nino 3.4 positif dan nilai SOI negatif. Apabila nilai indeks Nino 3.4 negatif dan nilai SOI yang positif, curah hujan yang terukur di keenam pos pengamatan curah hujan ini umumnya menunjukkan peningkatan.

Namun berdasarkan hasil penelitian, terdapat kondisi anomali dimana peningkatan SPL di wilayah Nino 3.4 dan penurunan nilai SOI tidak menyebabkan penurunan curah hujan di keenam pos pengamatan curah hujan di Semarang pada periode MAM. Pada periode ini, peningkatan anomali SPL di wilayah Nino 3.4 justru diiringi dengan peningkatan curah hujan di keenam pos pengamatan curah hujan di Semarang. Sementara itu, nilai SOI pada periode MAM memiliki korelasi yang negatif dengan variasi curah hujan di ke empat pos pengamatan curah hujan di Semarang, kecuali di Stasiun Meteorologi Maritim dan Genuk. Artinya, apabila nilai SOI meningkat, maka curah hujan di keempat pos pengamatan curah hujan tersebut cenderung mengalami penurunan. Namun korelasi indeks Nino 3.4 dan SOI terhadap curah hujan pada periode MAM dikategorikan tidak signifikan. Artinya bisa jadi pengaruh ENSO tidak terlalu signifikan di keenam pos pengamatan pada periode MAM.

Diantara semua periode penelitian, indeks Nino 3.4 dan SOI memberikan dampak dan hubungan paling signifikan pada curah hujan pada periode bulan September-Oktober-November. Pada periode SON, indeks Nino 3.4 memiliki korelasi yang signifikan dengan variasi curah hujan diamati di 5 pos pengamatan hujan dengan rentang antara -0.598 (cukup kuat) sampai -0.679 (kuat). Jika dibandingkan dengan indeks Nino 3.4, SOI memiliki korelasi yang lebih signifikan dengan variasi curah hujan diamati di 6 pos pengamatan hujan dengan rentang antara 0.561 (cukup kuat) hingga 0.779 (kuat). Artinya fenomena ENSO akan memberikan dampak yang paling kuat atau signifikan di ke enam pos pengamatan curah hujan di Semarang apabila terjadi pada periode SON.

\section{DAFTAR PUSTAKA}

Aldrian, E. (2002). Spatial Patterns of ENSO Impact on Indonesian Rainfall. Jurnal Sains \& Teknologi Modifikasi Cuaca, 3(1), 5-15.

Aldrian, E. (2008). Meteorologi Laut Indonesia. Jakarta: Puslitbang BMKG.

Aldrian, E., Karmini, M., Budiman. (2011). Adaptasi dan Mitigasi Perubahan Iklim di Indonesia. Pusat Perubahan Iklim dan
Kualitas Udara, Kedeputian Bidang Klimatologi, Badan Meteorologi, Klimatologi, dan Geofisika.

BPBD Kota Semarang. (2015). Laporan Kegiatan Pengkajian, Verifikasi dan Rekonstruksi Pasca Bencana Kota Semarang. Semarang: BPBD.

Fitria, W., Pratama, M.S. (2013). Pengaruh Fenomena El Niño 1997 dan La Niña 1999 Terhadap Curah Hujan di Biak. Jurnal Meteorologi dan Geofisika, 14(2), 65-74.

llahude, A.G., Nontji, A. (1999). Oseanografi Indonesia dan Perubahan Iklim Global (EI Nino dan La Nina). Puslitbang OseanologiLIPI. Jakarta, 1-13.

Kovats, R. S. (2000). El Niño and Human Health. Bulletin of the World Health Organization, 78(9), 1127-1135.

Luo, J.J., Zhang, R., Behera, S.K., Masumoto, Y., Jin, F.F., Lukas, R., Yamagata, T. (2010). Interaction between El Nino and Extreme Indian Ocean Dipole. Journal of Climate, 23(3), 726-742. doi: 10.1175/2009JCLI3104.1

Philander, S.G. (1989). El Niño, La Niña and the Southern Oscillation, San Diego: Academic Press.

Pratiwi, R.D. Nugraha, A.L., Hani'ah. (2016). Pemetaan Multi Bencana Kota Semarang. Jurnal Geodesi Undip, 5(4), 122-131.

Sugiyono. (2012). Statistika Untuk Penelitian. CV Alfabeta: Bandung.

Suwandi., Zaim, Y., Tjasyono, B. (2014). Pengaruh Aktivitas ENSO dan Dipole Mode terhadap Pola Hujan di Wilayah Maluku dan Papua Selama Periode Seratus Tahun (1901-2000). Jurnal Meteorologi dan Geofisika, 15(1), 71-76.

Tjasyono, B. (2008). Sains Atmosfer. Jakarta: Puslitbang BMKG.

Utami, A.W., Jamhari., Hardyastuti, S. (2011). El Nino, La Nina, dan Penawaran Pangan di Jawa, Indonesia. Jurnal Ekonomi Pembangunan, 12(2), 257-271.

Wang, C., Deser, C., Yu, J.Y., DiNezio, P., Clement, A. (2017). El Nino and Southern Oscillation (ENSO): A Review. Coral Reefs of the Eastern Tropical Pacific, 8, 85-106. doi: 10.1007/978-94-017-7499-4_4

Xiao, H., Mechoso, C.R. (2009). Seasonal CycleEl Niño Relationship: Validation of Hypotheses. Journal of the Atmospheric Sciences, 66(6), 1633-1653. doi: 10.1175/2008JAS2870.1

Yamagata, T., Behera, S.K., Rao, S.A., Guan, Z., Ashok, K., Saji, H.N. (2002). The Indian Ocean Dipole: A Physical Entity. CLIVAR Exchanges 24(7).

Zakir, A., Sulistya, W., Khotimah, M.K. (2009). Perspektif Operasional Cuaca Tropis. Jakarta: Puslitbang BMKG. 